\title{
0 Rio e sua indústria da música
}

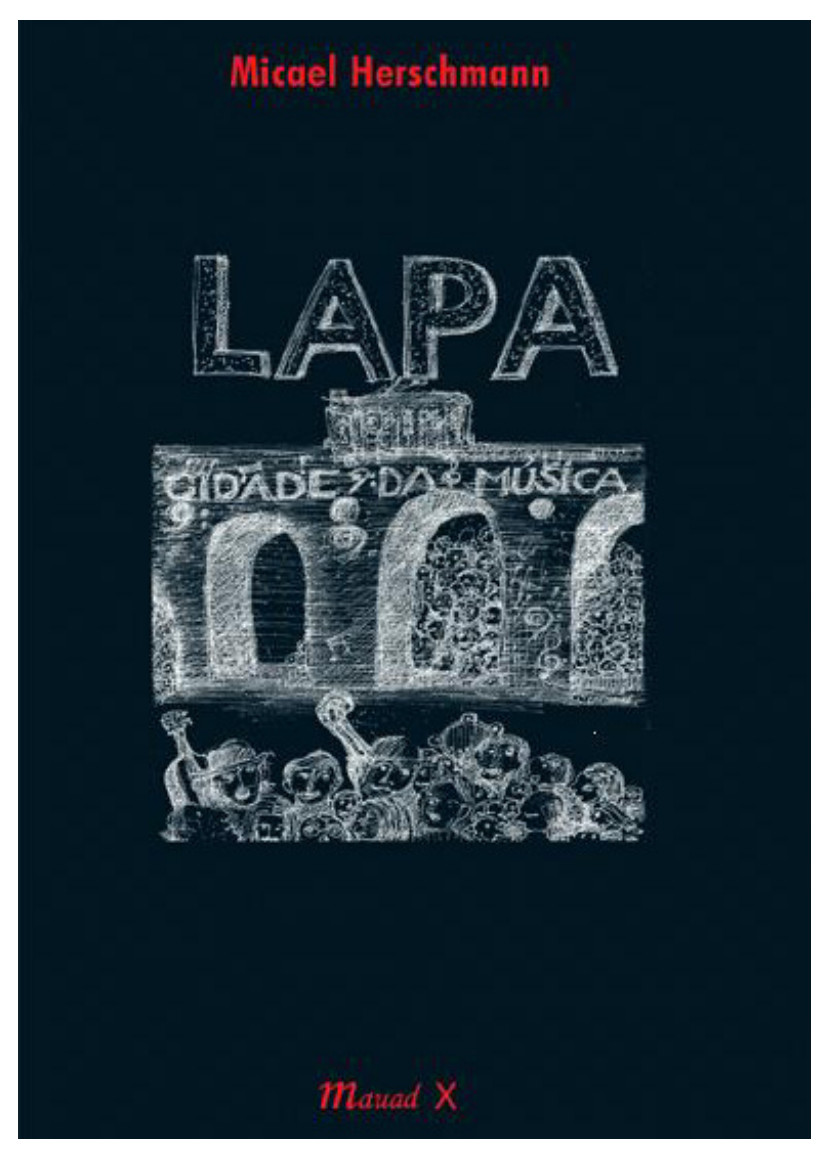

HERSCHMANN, Micael. Lapa, Cidade da Música. Rio de Janeiro, Ed. Mauad X, 2007.
De uma maneira geral, na cidade do Rio de Janeiro as diversas formas de expressão musical parecem estar associadas, por diferentes motivos e épocas, a determinados lugares: o samba aos subúrbios e às favelas, a Bossa Nova à zona sul, o funk e o hip-hop às favelas, o forró à Feira de São Cristóvão e assim por diante. Tratase, é claro, de um vínculo de forma alguma exclusivo, posto que a música é, por definição, desterritorializante. $\mathrm{O}$ forró anima a cidade durante as festas juninas e o samba renasce com mais força na época do carnaval. Digamos que se trata de uma aliança estratégica entre a música e o lugar, muitas vezes mais simbólica do que real, de modo a manter ativos os contornos da sua singularização.

O exercício conceitual proposto por Herschmann no livro LAPA - Cidade da Música, recentemente publicado pela Editora Mauad X, é justamente o de explorar essa aliança na Lapa, bairro popular do centro da cidade do Rio de Janeiro, que hoje se caracteriza pela presença marcante de shows de música ao vivo.

Como o próprio autor argumenta, nos últimos anos, a Lapa vem passando por transformações importantes, sobretudo em termos urbanísticos e de serviços de entretenimento (casas de shows, bares, restaurantes). Em grande medida, essa transformação foi alavancada pelo interesse na chamada "música de raiz", no caso o samba e o choro (ou "chorinho"), que conta com a participação de um enorme contingente de músicos jovens atraídos pela revalorização destas composições populares feitas na cidade, no final do século XIX. Não que outras expressões musicais não se façam presentes no local, mas o samba e o choro conseguiram constituir uma aliança mais vigorosa com a Lapa pelo seu forte apelo cultural, vinculado a questões identitárias da cidade e do país. Diferentemente de outras alianças originadas de forma mais espontânea e dispersa, entretanto, a Lapa se caracteriza por uma decidida ação empresarial concentrada em algumas ruas do bairro, que soube avaliar corretamente a dimensão econômica do lugar com relação ao samba e o choro. Sem dúvida, a presença dos antiquários da Rua do Lavradio em muito contribuiram para isso (como aconteceu também em Buenos Aires com o tango e o antigo bairro de San Telmo). Daí a acertadíssima recuperação feita pelo autor do conceito de soundscape, que designa a possibilidade da experiência de imersão provocada pela associação entre paisagem e música.

A partir dessa constatação da relevância desta aliança, o trabalho orienta-se no sentido de dois deslocamentos conceituais: o da indústria da música e o das políticas públicas. Com relação à indústria da música, a problematização é focada no embate entre as majors e as indies, isto é, entre as estratégias comerciais das grandes gravadoras e as produtoras independentes. A escolha

\section{Gerardo Silva} UFRJ 
desse primeiro deslocamentos se justifica amplamente na medida em que o samba e o choro da Lapa vinculamse à dinâmica das indies. Assim, a sustentabilidade empresarial da aliança depende, em grande medida, da forma em que as produtoras independentes conseguem produzir e difundir a "música de raiz", o que representa uma tarefa para nada fácil no contexto global de uma agressiva concentração de poder das majors na definição da grade musical dos meios de comunicação e do mercado consumidor. As novas tecnologias de informação e comunicação, evidentemente, permitem aos produtores independentes furar o cerco, porém de um modo ainda precário diante do tamanho de desafio colocado e aqui caberia problematizar de maneira mais vigorosa a produção cultural/musical da Lapa em relação às alternativas do software livre e o copyleft.

Com relação às políticas públicas, o segundo deslocamento conceitual do livro, o autor nos propõe chamar a presença do Estado como parceiro de um processo de desenvolvimento local. E aqui a definição de desenvolvimento local faz uma grande diferença. Seguindo a trilha aberta pelo conjunto de autores e obras que, no Brasil e em outros lugares do mundo, confirmam que o fortalecimento do desenvolvimento local, em suas diversas formas, é a via principal de integração social, institucional, econômica e cultural dos territórios, a obra nos conduz à necessidade de valorizar as redes de atores locais como condição sine qua non para qualquer proposta de intervenção na Lapa. Desse modo, as políticas públicas, por sua vez imprenscindíveis, poderiam ser endogeneizadas sem colocar em risco o que foi conquistado, isto é, uma aliança produtiva de cunho local, dificil de construir e muito fácil de destruir. Como afirma o próprio autor: "É preciso incentivar a criação de um ambiente de governança em que todos os atores estejam representados e em diálogo" (p. 199).

Há, ainda, outro grande mérito no livro. É o fato dele ter sido produzido criando as próprias fontes de informação primária. A quase inexistência de dados relevantes e confiáveis para quem trabalha com economia da cultura no Brasil é um empecilho muito dificil do contornar. Ainda assim, o autor consegue embasar o núcleo da sua argumentação em entrevistas, realizadas por ele mesmo, bem representativas do universo de questões que atravessam o território da Lapa. No livro, o problema da falta de informações foi compensado com inteligência tanto no uso das fontes disponíveis (primárias e secundárias) quanto na organização das partes e dos capítulos e na utilização de uma linguagem amena e precisa.Last but not least, a edição de LAPA - Cidade da Música, traz na orelha um texto de Hermano Vianna e vem acompanhada ainda de um belíssimo ensaio fotográfico de Antonio Fatorelli e Victa de Carvalho que os leitores terão oportunidade de apreciar wFAMEcos 